\title{
ИССЛЕДОВАНИЕ АРХЕОЛОГИЧЕСКИХ ПАМЯТНИКОВ НА СОПКЕ САРЫАДЫР (археология и высотная съемка)
}

\author{
(C) 2021 г. Эмма Радиковна Усманова ${ }^{1}$, \\ Джамбул Азмуханович Джумабеков ${ }^{1}$, \\ Ерболат Жаксыбекович Рахманкулов ${ }^{2}$, \\ Айдын Сенгалиевич Жунисханов ${ }^{3}$, Сырым Ғадылбекұлы Есен ${ }^{3}$
}

${ }^{1}$ научный сотрудник, Сарыаркинский археологический институт, НАО «Карагандинский университет им. академика Е.А. Букетова», г. Караганды, Казахстан. E-mail: emmadervish2004@mail.ru;

${ }^{1}$ кандидат исторических наук, декан исторического факультета, НАО «Карагандинский университет им. академика Е.А. Букетова», г. Караганды, Казахстан. E-mail: azmukhan@mail.ru;

${ }^{2}$ научный сотрудник, Государственный историко-культурный музей-заповедник “Бозок”, г. Нур-Султан, Казахстан. E-mail: mr.doublecherry@mail.ru; ${ }^{3} \mathrm{PhD}$ докторант, Евразийский национальный университет им. Л.Н. Гумилева, г. Нур-Султан, Казахстан. E-mail: aidun1985@gmail.com;

${ }^{3} \mathrm{PhD}$ докторант, Евразийский национальный университет им. Л.Н. Гумилева, г. Нур-Султан, Казахстан. E-mail: syrymesenov@gmail.com

Аннотация. В статье представлены результаты исследования двух погребальных сооружений на сопке Сарыадыр (п. Коргасын, Улытауский р-н, Карагандинская обл.). Объекты находятся в районе горной гряды Караторгай, которая расположена параллельно течению р. Караторгай. Данная местность в археологическом отношении мало изучена. Археологические раскопки в комплексе с высотной съемкой позволили выявить особенности расположения памятников в местном ландшафте. Культурнохронологическая позиция сооружений была определена по особенностям погребального обряда. Сооружение Сарыадыр 1 - это каменная выкладка с вертикальными стелами относится к поздней кыпчакской погребальной традиции XIII - первой половины $\mathrm{XIV}$ в. Оригинальным является захоронение в виде композиции из отдельных частей ног с инвентарем (железный нож и наконечник стрелы). Другое сооружение курган Сарыадыр 2, по всей видимости, имеет поминальный характер и относится к разряду кенотафов. В его конструкции обнаружена стела типа «койтас», которая лежала плашмя. Ритуальное сооружение относится к бегазы-дандыбаевской культуре эпохи поздней бронзы. Сравнительный анализ значения топонима Сарыадыр с архаикой обрядов раскопанных сооружений обозначил сакральное значение сопки в контексте культуры кочевников Улытау.

Ключевые слова: археология, кыпчакская погребальная традиция, стела, койтас, бегазы-дандыбаевская культура, топоним

Работа выполнена в рамках грантового финансирования Комитета науки МОН РК, ИРН проекта АР05132595 


\section{САРЫАДЫР ШОҚЫСЫНДАҒЫ АРХЕОЛОГИЯЛЫК ЕСКЕРТКІШТЕРДІ ЗЕРТТЕУ (археология және биіктік түсірілім)}

\section{Эмма Радиковна Усманова ${ }^{1}$, Жамбыл Әзмұқанұлы Жұмабеков ${ }^{1}$, Ерболат Жақсыбекұлы Рақманқұлов ${ }^{2}$, Айдын Сенғалиұлы Жүнісханов ${ }^{3}$, Сырым Ғадылбекұлы Есен}

${ }^{1}$ ғылыми қызметкер, Сарыарқа археологиялық институты, академик Е.А. Бөкетов атындағы Қарағанды университеті, Қарағанды қ., Қазақстан. E-mail: emmadervish2004@mail.ru;

${ }^{1}$ тарих ғылымдарының кандидаты, тарих факультетінің деканы, академик Е.А. Бөкетов атындағы Қарағанды университеті,

Қарағанды қ., Қазақстан. E-mail: azmukhan@mail.ru;

2 ғылыми қызметкер, «Бозоқ» Мемлекеттік тарихи-мәдени қорық музейі, Нұр-Сұлтан қ., Қазақстан. E-mail: mr.doublecherry@mail.ru;

${ }^{3} \mathrm{PhD}$ докторант, Л.Н. Гумилев атындағы Еуразия ұлттық университеті, Нұр-Сұлтан қ., Қазақстан. E-mail: aidun1985@gmail.com;

${ }^{3} \mathrm{PhD}$ докторанты, Л.Н. Гумилев атындағы Еуразия ұлттық университеті, Нұр-Сұлтан қ., Қазақстан. E-mail: syrym.e@mail.ru

Аннотация. Мақалада Сарыадыр шоқысында (Қарағанды облысы, Ұлытау ауданы, Қорғасын ауылы) зерттелген екі жерлеу құрылысының нәтижелері баяндалады. Нысан Қараторғай тау тізбегіне жатады және Қараторғай өзенінің бойында орналасқан. Археологиялық тұрғыдан аймақ өте аз зерттелген. Биіктен түсірілген суреттер мен археологиялық зерттеу жұмыстары жергілікті ландшафтыда ескерткіштердің орналасу ерекшеліктерін анықтауға мүмкіндік берді. Құрылыстың мәдени-хронологиялық шегі жерлеу ғұрпының негізінде анықталды. Тігінен қойылған тұғыртас бар, тас құрылысты Сарыадыр 1 құрылысы - XIII-XIV ғасырдың бірінші жартысымен мерзімделетін кейінгі қыпшақ заманының жерлеу дәстүріне тән ескерткіш. Адамның аяқ сүйектерінің жекелеген бөліктерін темір пышақ және жебе ұшы сияқты ахіреттік заттарымен қоса жерлеу өзіндік ерекше бір жерлеу дәстүрі болып табылады. Сарыадыр 2 - аза тұту мақсатында тұрғызылған оба болуы мүмкін және ол кенотафтар қатарына жатады. Тас конструкциядан «қойтас» типіндегі тұғыртас анықталды. Ескерткіш соңғы қола дәуірінің Беғазы - Дәндібай мәдениетіне тиесілі. Сарыадыр топонимін зерттелген нысандарда жасалған көне рәсімдермен салыстырмалы талдау нәтижелері аталмыш шоқының Ұлытау өңірінің көшпелілерінің мәдениетінде сакралды мәнге ие болғандығын көрсетті.

Тұйін сөздер: археология, қыпшақ жерлеу дәстүрі, тұғыртас, Беғазы-Дәндібай мәдениеті, топоним

\section{RESEARCH OF ARCHAEOLOGICAL SITES ON THE HILL SARYADYR (archeology \& altitude shooting)}

\section{Emma R. Usmanova ${ }^{1}$, Jambul A. Jumabekov ${ }^{1}$, Erbolat Zh. Rakhmankulov ${ }^{2}$, Aydin S. Zhuniskhanov ${ }^{3}$, Syrym Yessen ${ }^{3}$}

${ }^{1}$ Researcher, Saryarka Archaeological Institute, Buketov University, Karagandy, Kazakhstan. E-mail: emmadervish2004@mail.ru;

${ }^{1} \mathrm{PhD}$, Dean of the Faculty of History, Buketov Karagandy University,

Karagandy, Kazakhstan. E-mail: azmukhan@mail.ru;

${ }^{2}$ Researcher, "Bozok State Historical and Cultural Museum-Reserve", Nur-Sultan, Kazakhstan. E-mail: mr.doublecherry@mail.ru;

${ }^{3} \mathrm{PhD}$ student, Eurasian National University named after L.N. Gumilyov, Nur-Sultan, Kazakhstan. E-mail: aidun1985@gmail.com;

${ }^{3} \mathrm{PhD}$ student, Eurasian National University named after L.N. Gumilyov, Nur-Sultan, Kazakhstan. E-mail: syrymesenov@gmail.com 


\begin{abstract}
The article presents the results of a study of two burial structures on the Saryadyr hill (Karagandy region, Ulytau district, Korgasyn village). The objects are located in the area of the Karatorgay mountain range paralleled to Karatorgay river. This area is unknown in archaeological researching. Archaeological excavations in combination with high-altitude survey revealed the features of the location of sites in the local landscape. The cultural and chronological position of the structures was determined by the peculiarities of the funeral rite. The Saryadyr 1 is a stone structure with vertical steles belonging to the late Kypchak burial tradition of the $13^{\text {th }}-$ first half of the $14^{\text {th }}$ centuries. The original burial rite is in the form of a composition of individual parts of the legs with inventory such as an iron knife and an arrowhead. Another structure, the Saryadyr 2 mound, apparently had a memorial character and belonged to the category of cenotaphs. A lying flat stele of the type of "koytas" was in its design. The ritual structure belongs to the Begazy-Dandybay culture of the late Bronze age. A comparative analysis of the meaning of the toponym Saryadyr with the archaic rites of the excavated structures indicated the sacred significance of the hill in the context of the culture of the nomads of Ulytau.
\end{abstract}

Keywords: archaeology, Kypchak burial tradition, stele, koytas, Begazy-Dandybay culture, toponym

\section{Введение}

В сентябре 2020 г. было исследовано два археологических объекта, расположенных в 14 км к северозападу от п. Коргасын (Улытауский p-н, Карагандинская обл.). Цель изысканий: высотная фиксация памятников истории в местном ландшафте и археологическое изучение объектов. В научном плане данный археологический микрорайон, который находится в ландшафте холмов, возвышенностей и узкой долины р. Караторгай, является «белым пятном». Группа новых погребальных памятников была обнаружена в ходе обследования этой местности директором «Национального историко-культурного и природного музея-заповедника Улытау» Б. С. Кожахметовым в 2018 г. В полевом сезоне 2020 г. было раскопано два погребальных сооружения, которые дополнили исторический контекст древностей Улытау.

Археологические объекты находятся в районе горного кряжа Караторгай, расположенного параллельно течению р. Караторгай. На правой стороне реки находятся высшие точки кряжа, который состоит из слюдяного и глинистых сланцев, сильно приподнятых и разрозненных гранитами, зеленокаменными породами (диабазы, диориты, габбро, порфириты). Вершины в виде отвесных утесов отличаются от остальных гор этого кряжа неправильным напластованием слюдяного сланца с жилами кварцитов и кристаллических сланцев. В утесах, расположенных при повороте реки на северо-запад, известны свинцовые прииски, открытые в 1814 г. [Геологическая характеристика месторождения Кургасын. Интернет-ресурс]. Местность характеризуется обнажениями вдоль речных бортов, наличием оврагов в виде небольших каньонов и ущелий с различного рода отложениями (лёссовидные суглинки и др.), которые смываются со склонов водными потоками [Караторгай, горный кряж. Интернет-ресурс]. Реки Караторгай и Жалдама берут свое начало на западной окраине Казахского мелкосопочника и, сливаясь, образуют исток реки Торгай. 
Усманова Э.Р., Джумабеков Д.А., Рахманкулов Е.Ж., Жунисханов А.С., Есен С.Ғ. Исследование ...

\section{Описание археологических ма-} териалов

Для археологических раскопок было выбрано два объекта на вершинах холмов под общим названием сопка Сарыадыр: группа погребальных сооружений Сарыадыр 1; курган Сарыадыр 2 (рис. 1). Следует отметить, что эта сопка по своей высоте является одной из главенствующей в окрестностях. С ее вершины открывается обзор местности на 10-20 км вокруг.
Групnа Cарыадыр 1. Состоит из трех погребальных сооружений, которые располагаются на одной линии и хорошо фиксируются на поверхности (UTM 49.249696 66.610911). Главное сооружение в виде каменного кургана диаметром около 8 м и высотой 0,8 м находится на вершине, от него вниз по ложбине по линии С3-ЮВ на расстоянии 50 и 70 м друг от друга располагаются два сооружения в виде каменных выкладок. Ложбина с покатыми склонами длиной до 500 м, шириной

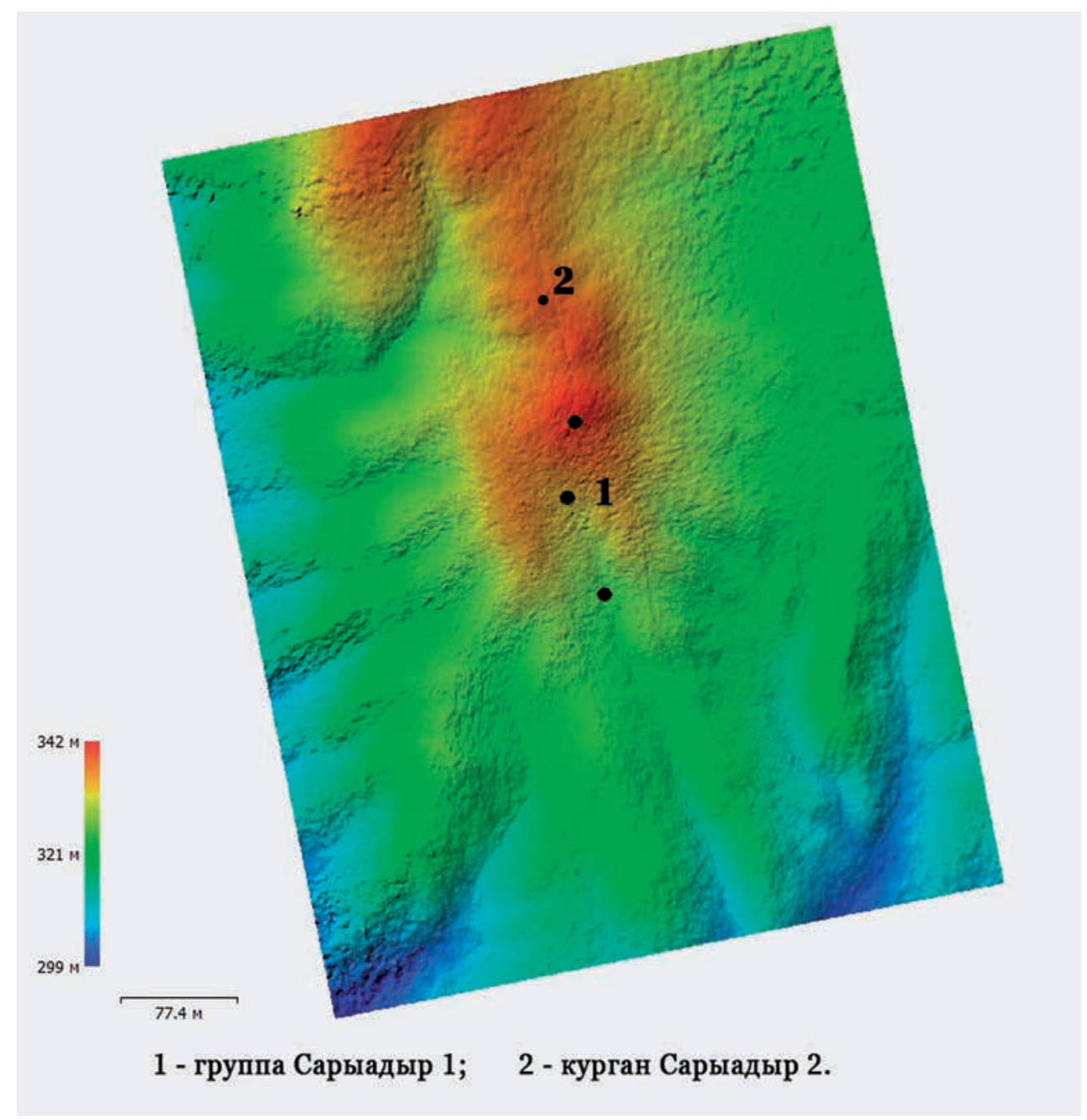

Рис. 1. Археологические объекты Сарыадыр 1 и 2. Ортофоплан и карта высот

Fig. 1 Archaeological site Saryadyr 1 and 2. Orthophoplan and elevation map 
до 10 м. Искусственная земляная насыпь не фиксировалась в сооружениях, за исключением лёссового заполнения из суглинка между камнями, которое образовалось за счет смыва со склона. Камни сооружений колотые (преимущество диабазы, диориты зеленоватого цвета с включением жил кварца) неправильной геометрической формы, размерами $0,4 \times 0,5-0,5 \times 0,6 \mathrm{~m}$. Две «ложбинные» выкладки имеют особенность в строении насыпи: поставленные в древности вертикально плиты подтреугольной формы, высотой до 1 м, которые со временем наклонились под углом. Предварительно форма выкладок определялась как четырехугольная размерами более четырех метров. Для археологического исследования было выбрано среднее погребальное сооружение 1, расположенное в центральной части ложбины между главным курганом и нижней выкладкой.

Курган Сарыадыр 2 находится на одной из вершин одноименной сопки в 150 м к северо-западу от основного кургана группы Сарыадыр 1 (UTM $49.25025066 .610923)$. Каменная насыпь высотой 0,5 м состоит из колотых камней разных пород (кварциты, порфириты, диориты) геометрической формы, размерами $0,3 \times 0,4-0,4 \times 0,6$ м. Сооружение «вписано» своей формой в скальный выход, камни которого органично вошли в конструкцию сооружения.

Группа Сарыадыр 1, погребальное сооружение 1. Вскрытие произведено на месте сооружения при помощи раскопа прямоугольной формы размерами $6 \times 6$ м, ориентированного по сторонам света, с центральной бровкой, направленной по линии C-Ю. После расчистки выявлена конструкция постройки в плане комбини- рованной формы: северная половина имела округлый контур, южная - контур подквадратной формы, размерами по сторонам света 4,3×4 м, высотой до 0,6 м (рис. 2). Другой деталью являлась пристройка с юго-восточной стороны сооружения, прямоугольной формы в виде двух плашмя положенных на расстоянии 0,9 м друг от друга камней длиной до 0,6 м (рис. 3).

Погребальное сооружение состояло из внешнего и внутреннего кольца с забутовкой в центре из мелкого камня размерами $0,2 \times 0,3$ м. Внешнее кольцо в виде крепиды состояло из камней геометрической формы с заостренным верхом, положенных плашмя и под углом, размерами $0,4 \times 0,5-0,4 \times 0,6$ м. Камни острыми концами наклонены к центру, нижними - к внешнему контуру кольца. Камни меньшего размера $0,15 \times 0,25$ м лежали внизу под наклоненными камнями и фиксировали их. Внутреннее кольцо состоит из камней вытянутой геометрической формы, уложенных по длине окружности к центру. Камни возвышаются над уровнем поверхности на высоту от 0,3 до 0,5-0,6 м (на чертеже указано в см).

Погребение. Выборка камня из центра и внутреннего кольца выявила чёткий контур ограды внешней крепиды как главной конструктивной детали сооружения высотой от 0,4 до 0,6 м, шириной $0,8-1,5$ м, в плане округлой формы, размерами $4,5 \times 4$ м (рис. 4). Внутри западной стороны ограды на уровне материка (-50-60 см) фиксировалась кладка высотой $0,3-0,4$ м из двух рядов плашмя положенных камней прямоугольной формы размерами $0,2 \times 0,3$ м. Заполнение внутри ограды - суглинок лессового происхождения с содержанием каменной крошки.

Следует отметить следующие особенности конструкции вы- 


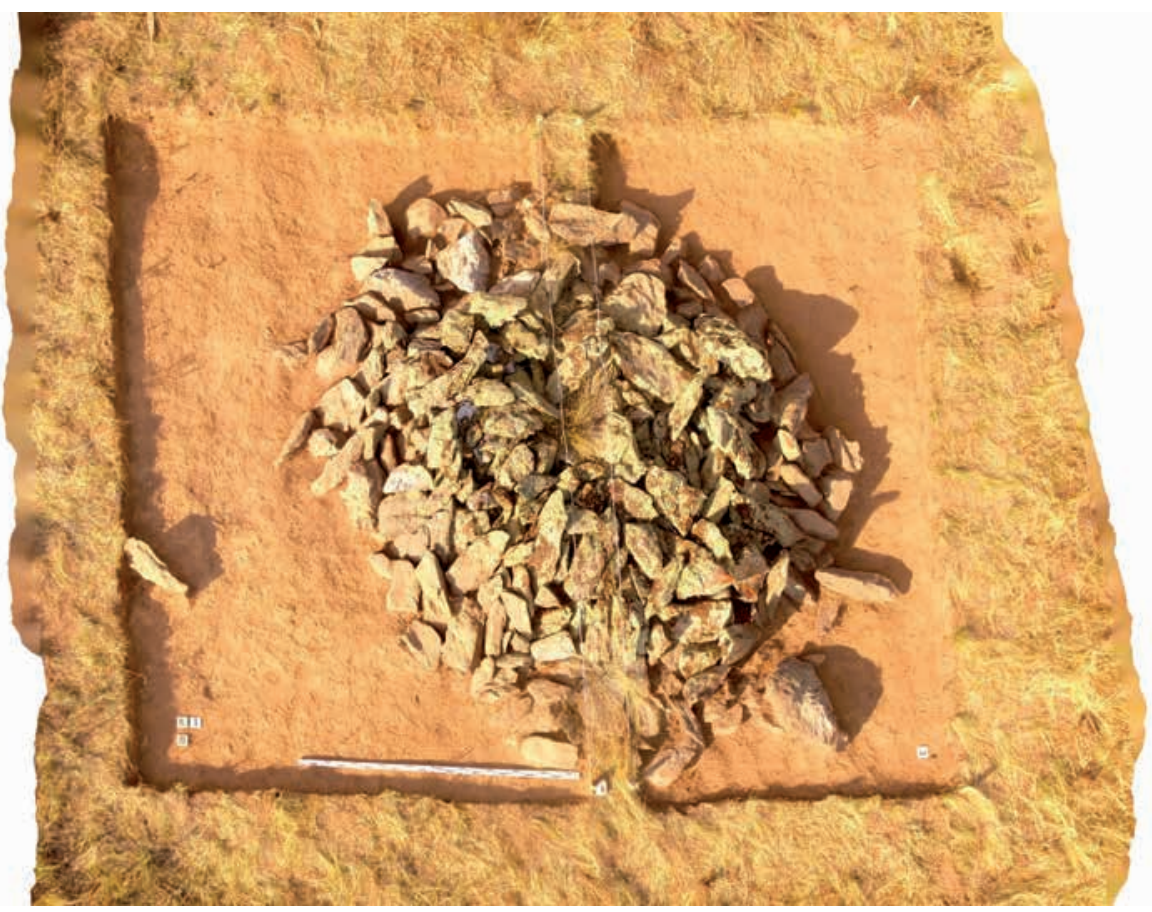

Рис. 2. Погребальное сооружение Сарыадыр 1. Общий вид после вскрытия

Fig. 2. Burial structure Saryadyr 1. General view after unearthed

кладки: в устройстве использованы камни одной породы - диориты; по двум сторонам (северо-западная и юго-восточная) было установлено по два камня, которые не имели следов видимой обработки, условно обозначенные как стелы. Они имели подтреугольную форму с острым верхним концом и отличались от других камней своими размерами: высота до от 0,7 до 1,2 м, ширина по основанию до 0,4-0,5 м. По всей видимости, первоначально они были поставлены вертикально и со временем наклонились в юго-восточном направлении под углом в $45-50^{\circ}$, и сейчас возвышаются над уровнем крепиды на $0,6-0,8$ м. Вертикальные плиты обозначены относительно сторон слева направо: С3 - № 1, 2; ЮВ - № 3, 4 (рис. 5).

Была расчищена внутриоградная площадка округлой формы раз- мерами 2,2×2,1 м (рис. 6). Очертания погребения фиксировались в западной стороне площадки по светлому и относительно мягкому характеру грунта заполнению по сравнению с материком. Могильная яма в плане прямоугольной формы с закругленными углами, размерами $1,7 \times 1 \mathrm{~m}$, ко дну сужается до размеров $1,3 \times 0,7 \mathrm{M}$, ориентирована по линии СС3-ЮВВ (рис. 7). Восточная половина площадки отличалась темным цветом грунта, скорее всего, это был уступ размерами $1,8 \times 0,8$ м, сделанный на материке для спуска в яму. Заполнение погребения - плотный суглинок с затеками. Создалось впечатление, что погребение было выдолблено в материке. Стенки ямы чуть пологие, дно плоское.

На глубине 0,6 м в центре дна ямы были обнаружены кости погребенного очень плохой сохранности. 


\section{ҚАЗАҚСТАН АРХЕОЛОГИЯСЫ № 1 (11) 2021}

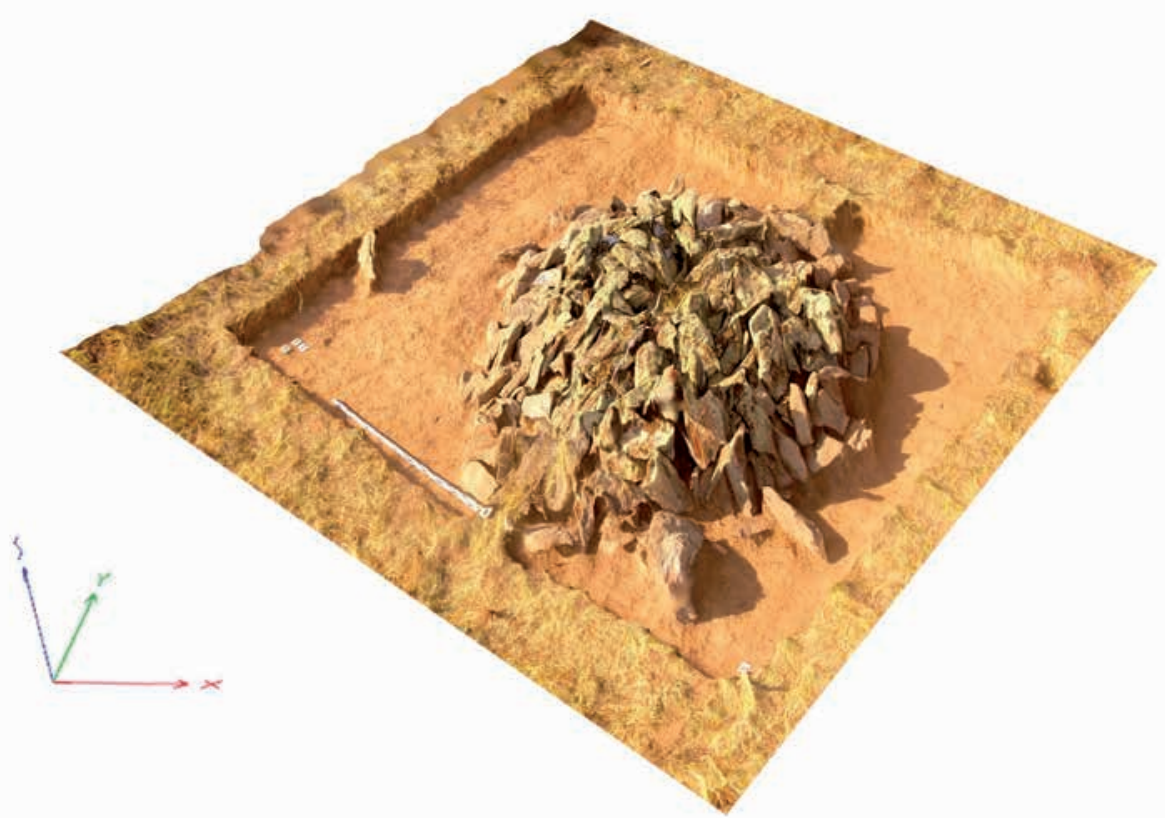

Рис. 3. Погребальное сооружение Сарыадыр 1. Общий вид после вскрытия

Fig. 3. Burial structure Saryadyr 1. General view after unearthed

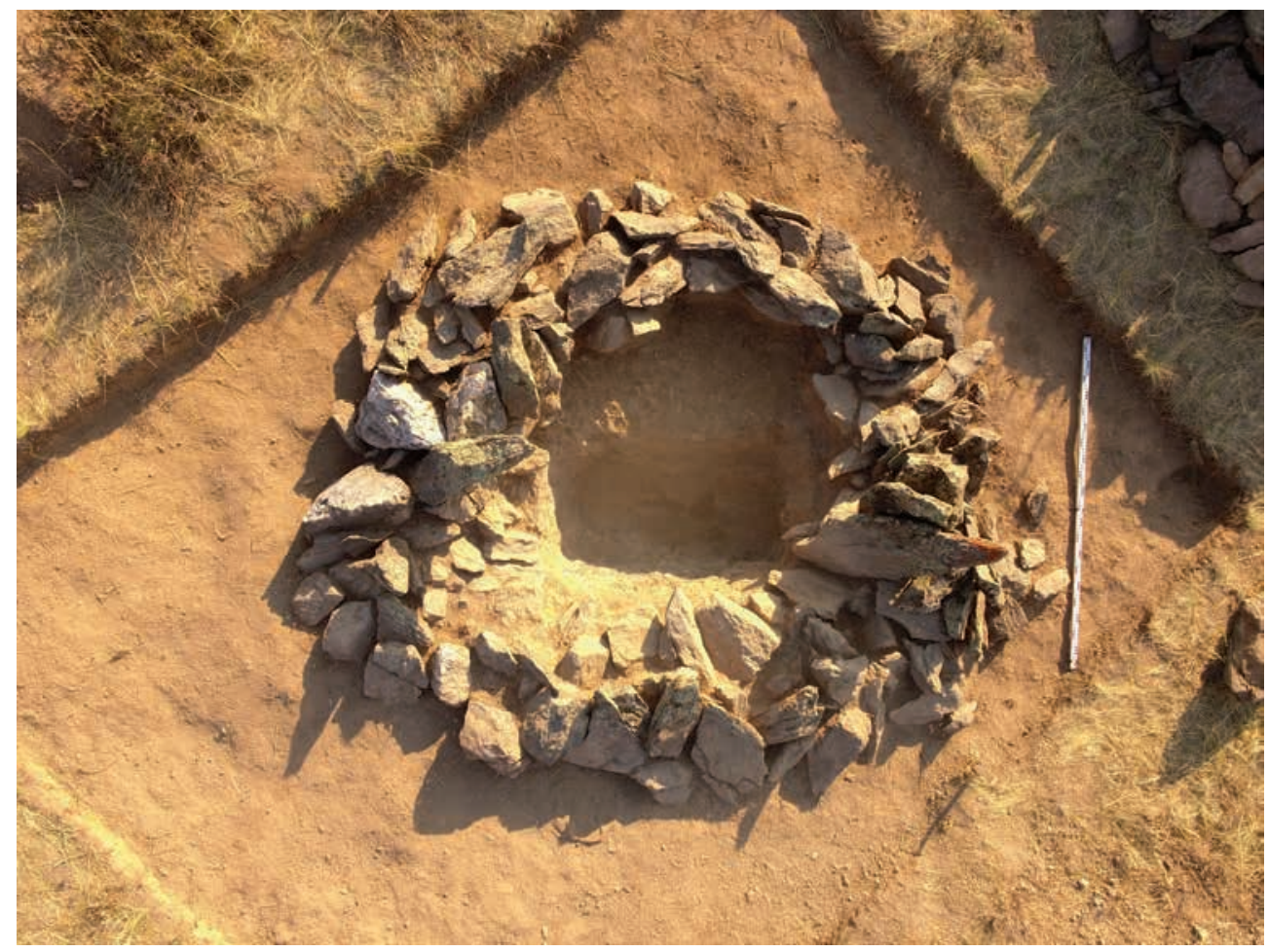

Рис. 4. Погребальное сооружение Сарыадыр 1. Вид кольца ограды

Fig. 4. Burial structure Saryadyr 1 


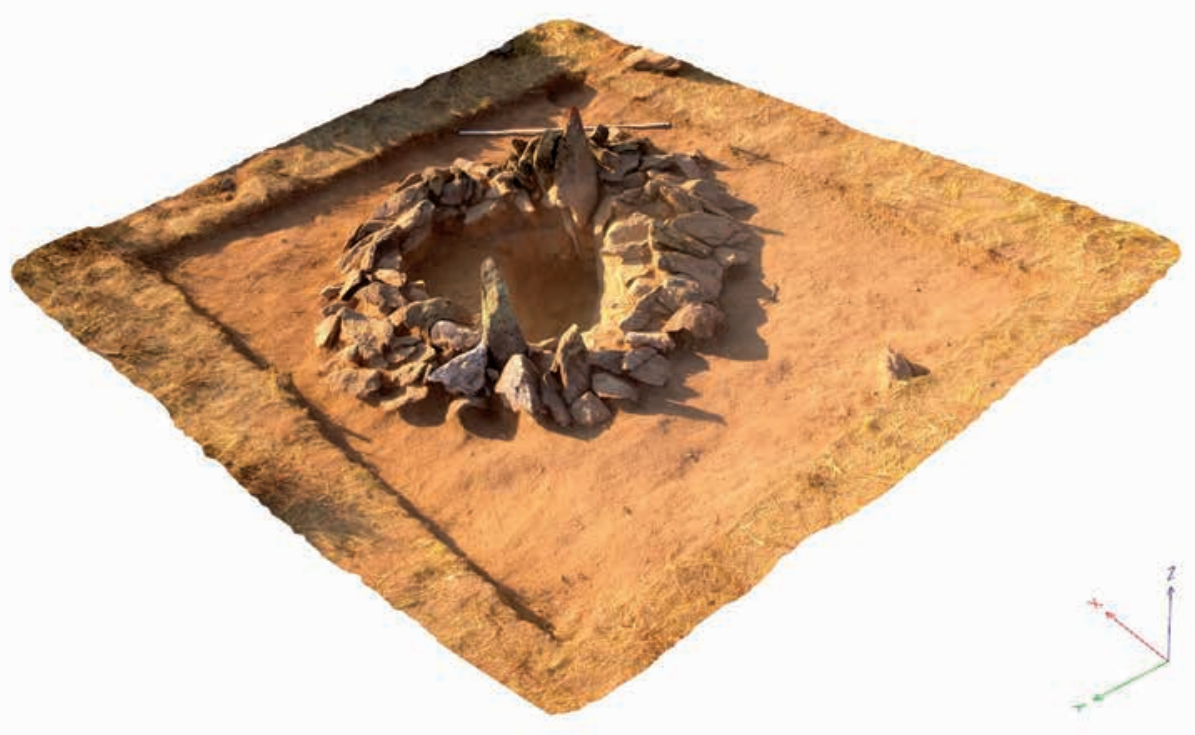

Рис. 5. Погребальное сооружение Сарыадыр 1. Вид стел

Fig. 5. Burial structure Saryadyr 1. View of the steles

Захоронение представляло собой неполный костяк в виде композиции из отдельно уложенных с сохранением анатомической последовательности бедренных и берцовых костей, ориентированных по линии СС3-ЮВВ, общей длиной 0,7 м с расстоянием между ними $0,2-0,25$ м. При этом отсутствовали другие части ног: коленные чашечки, кости ступней. Впрочем, иные части скелета также не обнаружены. Скорее всего, в могильную яму были помещены только отдельные кости скелета в виде частей ног погребенного, ориентировка которых соответствовала линии направленности менгиров. По всей видимости, погребение не было разрушено намеренным проникновением и представляло собой частичное захоронение костей погребенного. Из-за плохой сохранности не представляется возможным говорить о помещении в яму костей скелета, свободных от мышеч- ных тканей или отделенных ног от тела умершего.

В районе верхней части правой бедренной кости в 0,1 м от стенки могильной ямы был найден фрагмент пластинчатого черешкового железного наконечника (дротика?) со сломанным концом, возможно, треугольной формы, общей длиной около 8 см. У конца правой берцовой кости - железный черешковый наконечник стрелы, длиной 6 см, форма пера не сохранилась (треугольная?). Железо изделий плохой сохранности, поэтому установить точную форму предметов не удалось. Других находок не обнаружено. Вскрытая пристройка с южной стороны кольца не содержала находок. Очевидно, что на сохранность костей ног и железных вещей повлияло местонахождение сооружения в ложбине на пути следования потока воды, который замывал лессом погребение. 

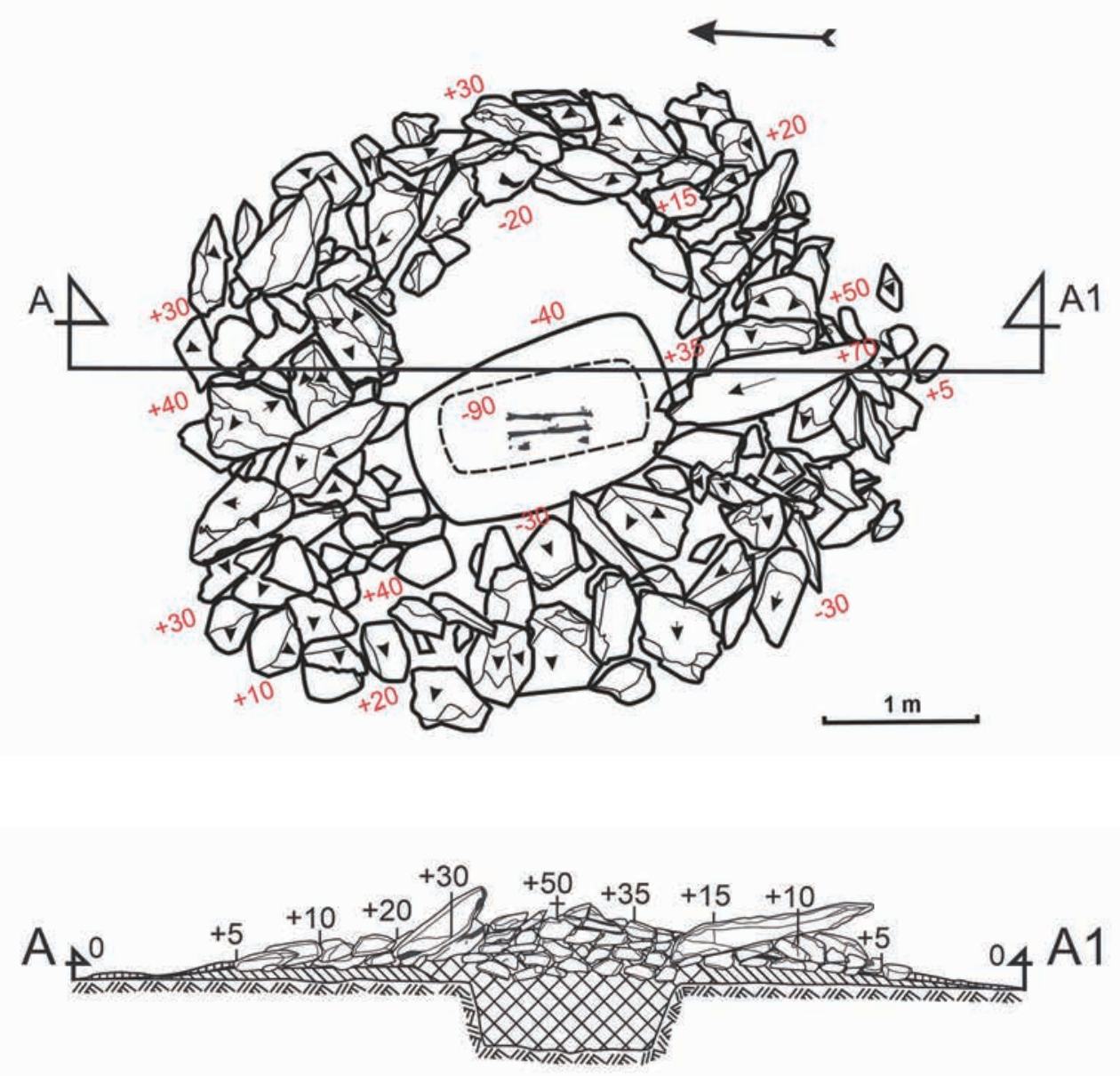

س] - дёрн
- светло-коричневый суглинок
- материк
- лёссовый суглинок

Рис. 6. Погребальное сооружение Сарыадыр 1. План и профиль Fig. 6. Burial structure Saryadyr 1. Plan and profile

С целью определения оригинальной характеристики стелы был вынут камень (ЮВ № 3) из крепиды, подтреугольной формы длиной 1,2 м, шириной $0,5-0,6$ м. Нижняя сторона была заострена в виде клина длиной до 0,3 м, видимо, предназначенного для установки среди камней ограды. Скорее всего, клин является результатом искусственного скола, хотя видимых следов намеренной подтески не обнаружено. Камень доставлен на хранение в музей-заповедник «Улытау».

Курган Capbladblp 2. Этот курган отличается по своим внешним характеристикам от погребальных сооружений группы Сарыадыр 1: не- 
большая высота до 0,5 м; камень насыпи небольших размеров $(0,3 \times 0,4-$ 0,3×0,5 м) представлен разными породами (кварциты, диориты, порфириты); использование в конструкции сооружения природных каменных выходов скалы; одиночное местонахождение на самой высокой точке холма; отсутствие двойного кольца крепиды.

Курган округлой формы диаметром 4 м. Вскрытие велось при помощи раскопа в плане округлой формы диаметром 4 м, с центральной бровкой, ориентированной по линии ССВЮЮЗ. Разрез профиля сооружения прошел по жиле скального выхода. По этой причине хорошо не фиксировался (на рисунке не указан). Особенностью конструкции насыпи является то, что контур западной половины кургана был вписан в камни скального выхода, что затрудняло расчистку подкурганной площадки (рис. 8). После выборки грунта (плотный суглинок с содержанием каменной крошки) и камней из центра насыпи обнажилось кольцо ограды, которое являлось главным конструктивным элементом этого погребального сооружения. Контур ограды имел комбинированную форму: западный - округлой формы, восточный - подквадратной. Длина сторон ограды: восточная половина размером 3,5-3,6 м; западная $3,1-3,2$ м. Ширина кольца $0,5-0,8$ м из плашмя уложенных камней размерами $0,3 \times 0,4-0,3 \times 0,5$ м. Некоторые камни прямоугольной формы $(0,4 \times 0,7$ м) были сложены в один ряд по западному контуру ограды.

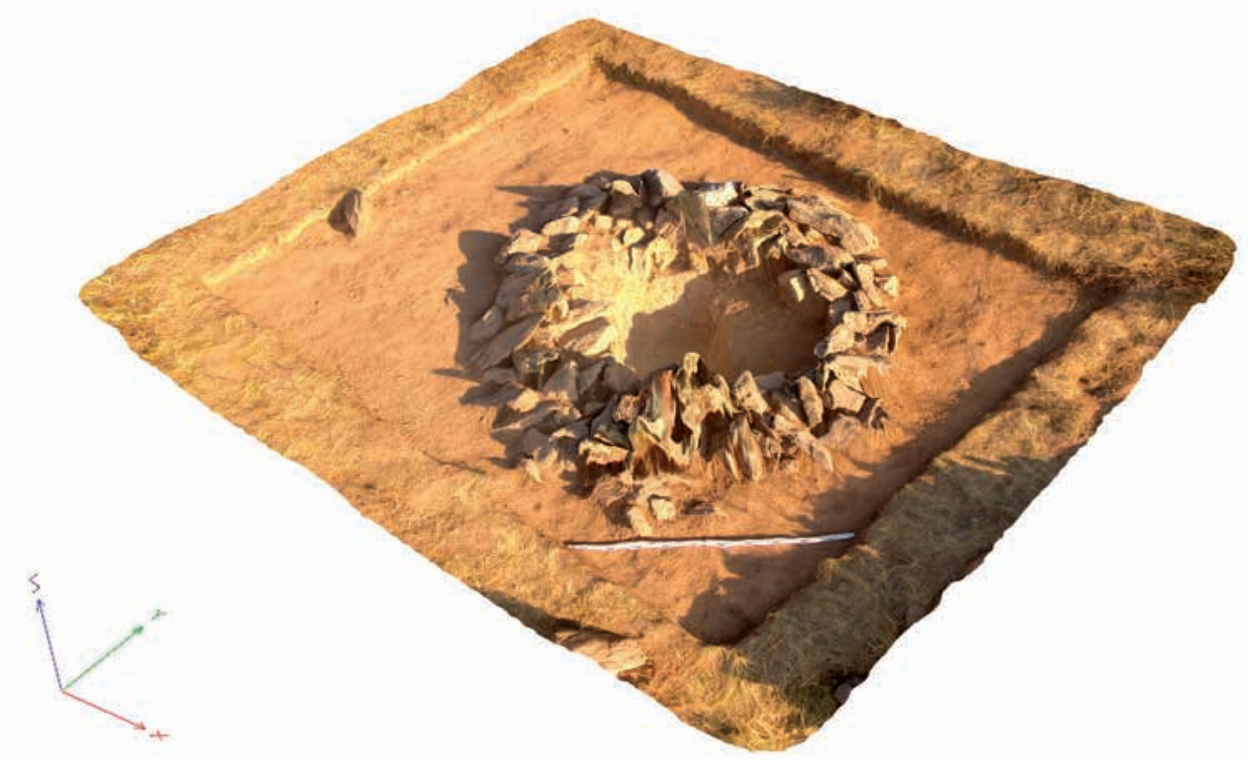

Рис. 7. Погребальное сооружение Сарыадыр 1. Вид погребения

Fig. 7. Burial structure Saryadyr 1. View of burial 


\section{ҚАЗАҚСТАН АРХЕОЛОГИЯСЫ № 1 (11) 2021}

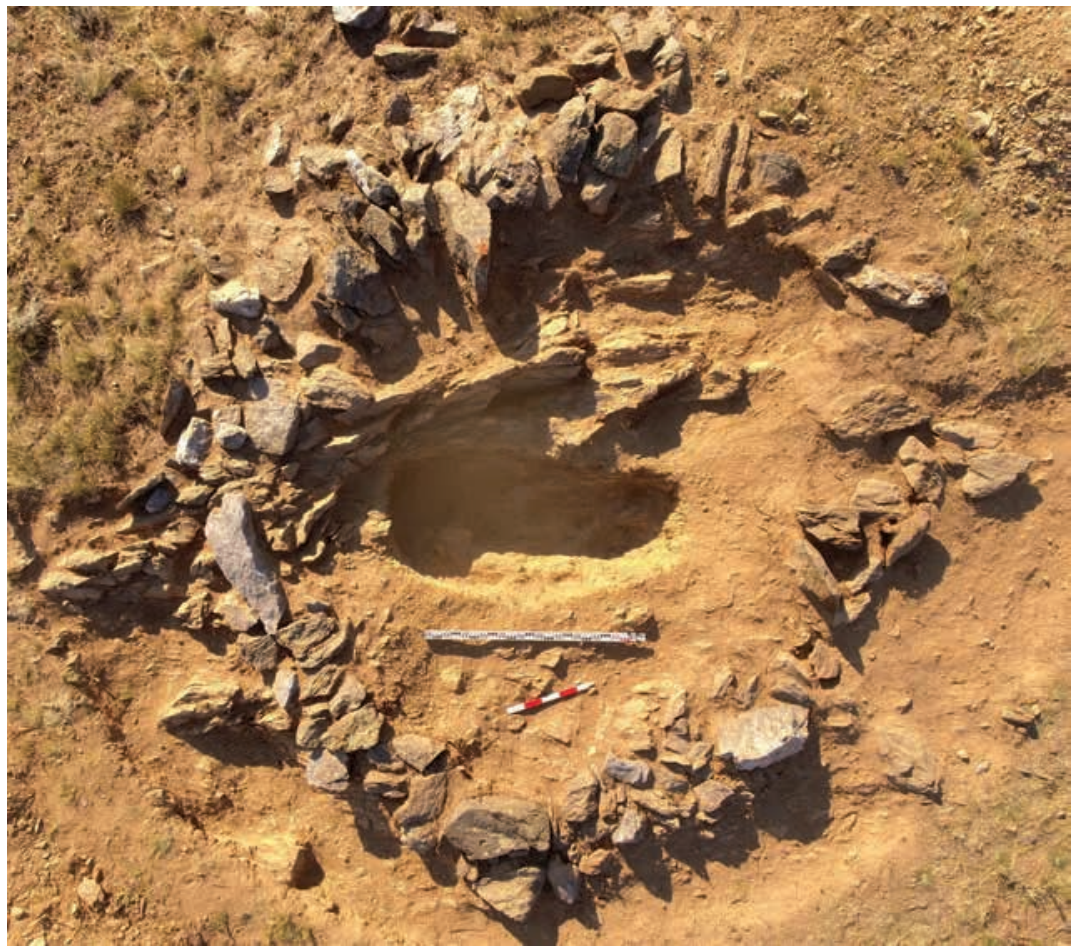

Рис. 8. Погребальное сооружение Сарыадыр 2. Вид после вскрытия Fig. 8. Burial structure Saryadyr 2. View after unearthed

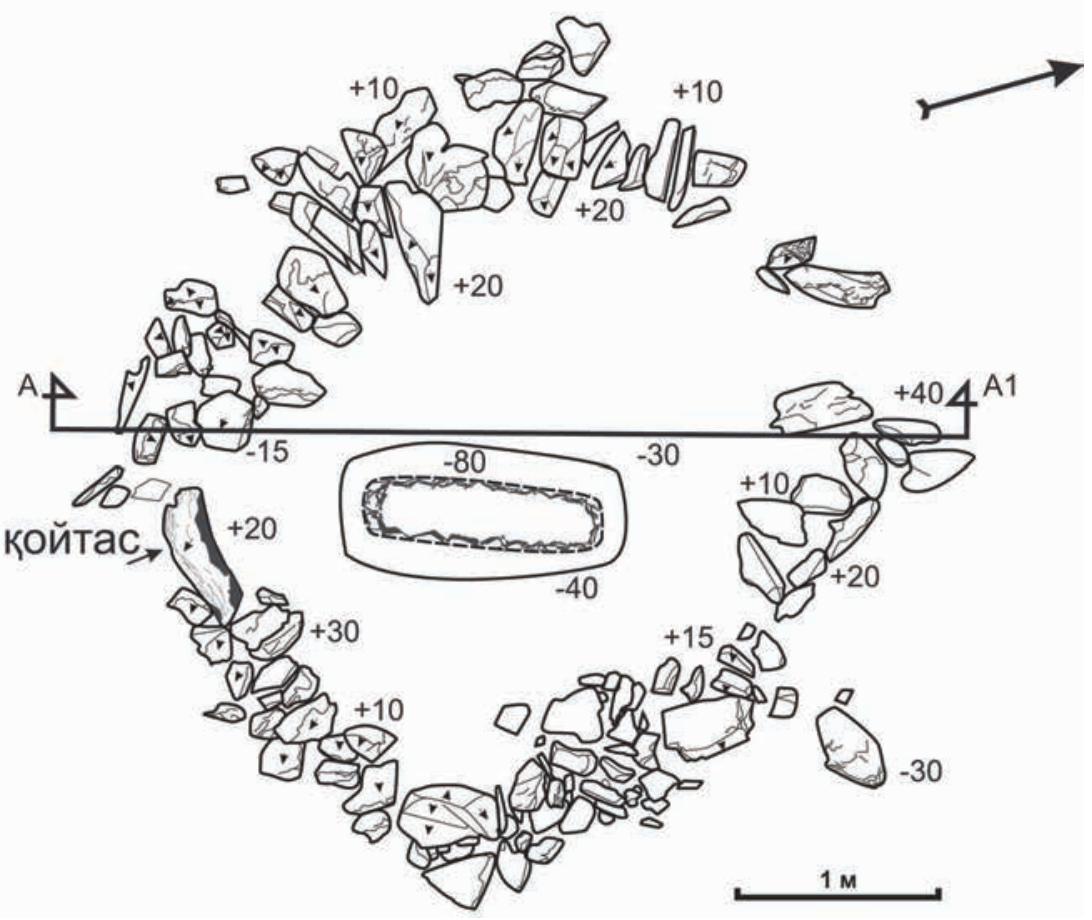

Рис. 9. Погребальное сооружение Сарыадыр 2. План

Fig. 9. Burial structure Saryadyr 2. Plan 


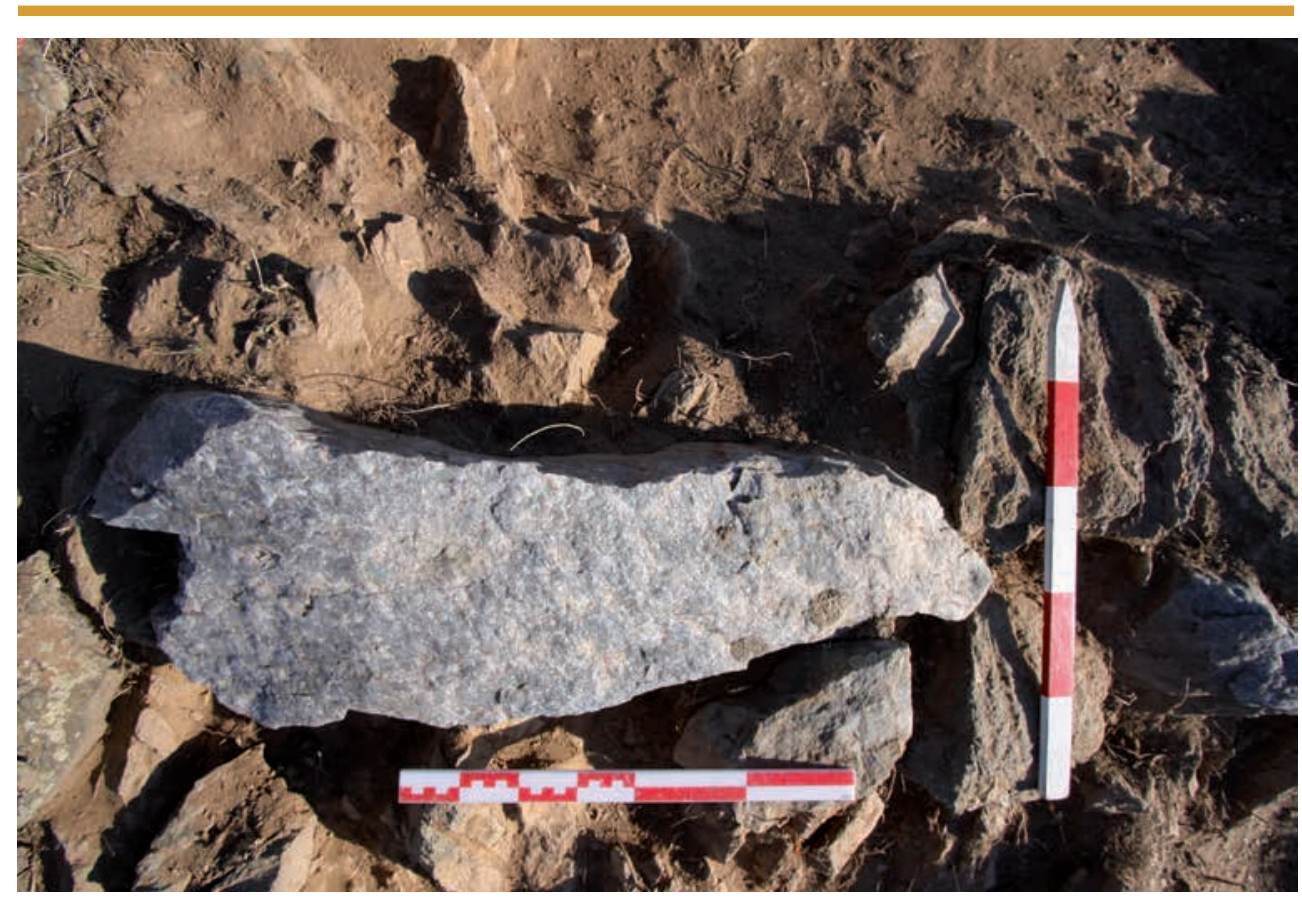

Рис. 10. Погребальное сооружение Сарыадыр 2. Вид стельи «койтас»

Fig. 10. Burial structure Saryadyr 2. View of the stele "koytas"

В центре подкурганной площадки подквадратной формы размерами около $3 \times 3$ м, вдоль восточной стороны скальной жилы длиной около 2 м, была вскрыта яма (рис. 9). Ее очертания едва фиксировались на уровне материка (-40 см). Вскрытие ямы осуществлялось на основании мягкого характера грунта заполнения. В результате была выявлена яма в плане овальной формы размерами $1,5 \times 0,6-0,8$ м $(1,3 \times 0,4$ м - у дна), ориентирована по линии С-Ю, глубиной 0,6 м. На ее дне фиксировались камни скального выхода. Яма пустая. Назначение ее не ясно, возможно, жертвенная или кенотаф.

Особенность погребальной конструкиии. В южном конце бровки юго-восточного сектора кольца была уложена плита из белого кварцита, которая заметно отличалась по своей форме от других камней ограды.
По конфигурации она очень напоминает так называемый койтас («бараний камень»). Плита подпрямоугольной формы длиной 105 см, шириной в основании $30 \mathrm{~cm}$, в узкой части $22 \mathrm{~cm}$, толщиной 10 см, в сечении прямоугольной формы (рис. 10). Верхняя часть оформлена в виде стилизованной морды барана, подтреугольной формы, длиной до $12 \mathrm{~cm}$, шириной 8 см. С одной стороны на поверхности плиты наблюдаются следы грубых сколов. Длинная сторона плиты, противоположная «морде», имеет небольшую вогнутость, скорее всего, искусственного происхождения. В ограде койтас лежал перпендикулярно по отношению к яме, с «мордой», повернутой к ее восточной стороне. Плита была уложена в кольцо ограды и, скорее всего, она не стояла вертикально. Своей формой она была «вписана» в кольцо ограды и составляла вместе 
с ней единый контур. Койтас доставлен на хранение в музей-заповедник «Улытау».

Обсуждение материалов, интерпретация и выводы

Культурно-хронологическая характеристика объектов. Группа Сарыадыр 1, погребальное сооружение 1 . На основании погребального обряда и, прежде всего, малочисленного инвентаря (черешковые, пластинчатые железные нож и наконечник стрелы), данное сооружение можно отнести к восточной группе кыпчакских погребений урало-казахстанских степей XII-XIII вв. [Могильников, 1981, с. $194-195$; с. 244 , рис. $72,74,77,86$, 87]. Для них характерна каменная выкладка над погребением, преимущественно 3-С3 ориентировки. Но погребальный ритуал этого сооружения не находит прямых аналогий в классической кыпчакской погребальной традиции: отсутствуют - конское захоронение, вещи военной атрибутики, быта, костюма. «В середине XIV в. в погребальном обряде кочевников происходят существенные изменения: из могил исчезают предметы конской сбруи, вооружения, большинство бытовых предметов <..>» [Иванов, Кригер, 1988, с. 31]. Ориентировка ССЗ-ЮВВ с вектором в сторону севера указывает на новые тенденции в оформлении погребального ритуала, которые связаны с изменением этнополитической картины периода Золотой Орды в Степи. Северная ориентировка погребений считается одной из отличительной черт монгольской культурной традиции «<...> представление о севере как направлении в страну мертвых, воспринятое, как полагают, у монгол, существовало и в тюркской среде» [Боталов, 2019, с. 270].
В контексте интерпретации погребение Сарыадыр 1 можно сравнить c погребениями урало-поволжских степей золотоордынского времени. Этот тип погребений связан с традицией племен, которые приходят из Сибири в составе монгольских войск. Для языческих кочевнических погребений восточной степной зоны XIII - первой половины XIV в. характерны каменная наброска-выкладка и каменное кольцо вокруг могилы [Иванов, 2013, с. 92-94]. Начинают преобладать такие признаки погребального обряда как северная ориентировка, простая могильная яма с вертикальным стенками, отсутствие костяков коней. Во второй половине XIV в. в связи с исламизацией кочевников Золотой Орды постепенно «уходят» многие языческие элементы из погребального обряда, происходит нивелировка компонентов инвентаря при сохранении в его составе престижных предметов типа украшений и монет [Иванов, Кригер, 1988, с. 41].

Вероятно, что погребение Сaрыадыр 1 по своим элементам обряда принадлежит поздней кыпчакской погребальной традиции XIII - первой половины XIV в., которая оформилась после прихода в степь монгольских племен (в данном случае монголы это политоним - прим. авт.). При этом погребальный ритуал лишен многих монгольских элементов, таких как вертикально вкопанная кость ноги овцы, кости животных, культовые предметы. Единственный элемент, который объединяет с монгольской погребальной традицией золотоордынского образца - это вертикально установленная стела в каменную выкладку [Усманова и др., 2018, с. 106-113].

Что касается каменных изваяний, которые являются знаковым ко- 
дом в половецко-кыпчакских ритуалах, то монгольское завоевание прервало существование этой системы хранения культурной информации [Бисембаев, 2003, с. 142]. Установка изваяний в кыпчакском обществе относится к культам поминального характера и не сопровождает погребальный ритуал, связанный с конкретной умершей личностью.

Оригинальный ритуал погребения Сарыадыр 1 - композиция на дне ямы из выложенных определённых частей костей ног умершего, четыре вертикальных стелы, отсутствие следов намеренного проникновения - указывает на его символический аспект со смещением в сторону поминального культа. В таком случае, кости ног могли символизировать отсутствующее тело умершего, стела представляла образ каменного изваяния.

Само погребение, спрятанное в ложбине, носило потаенный характер кенотофа - это тип погребения, который оформлялся в случае отсутствия костей погребенного или наличия лишь некоторых частей костяка. Можно предположить, что данное сооружение было выстроено с целью исполнения поминального культа, знаковый смысл которого кроется в системе кыпчакского мировоззрения.

Возможно, что идея кенотафа относится к воинскому характеру погребения, когда воин мог погибнуть где-нибудь на чужбине и до родного кочевья для похорон были доставлены лишь какие-то части тела. По своим ритуальным элементам погребение Сарыаадыр 1 является оригинальным проявлением степного кочевнического погребального обряда XIII - первой половины XIV в. Прямых аналогий данному погребению нами пока не найдено.
Похожее по некоторым деталям погребение было раскопано одними из авторов статьи (А. С. Жунисханов и Е. Ж. Рахманкулов) в ограде 1 могильника Елекесазы (Тарбагатайский p-н, Восточно-Казахстанская обл). Нетронутое погребение было впускным, в нем зафиксированы in situ нижние конечности (стопами вверх) погребенного в анатомическом порядке. Культурная принадлежность и дата погребения не определены. Этнографическая параллель погребению с характером кенотафа с символическим захоронением какой либо части тела известна в легенде о батыpe Байеш. Недалеко от села Актубек (Жанааркинский р-н, Карагандинская обл.) располагается сопка под названием Байеш. По легенде здесь захоронен средний палец (по другой версии - мизинец) известного батыра Байеша из рода Алтай-Алысай, который погиб на войне с джунгарами. Батыр Байеш перед смертью отрезал себе средний палец и завещал (аманат) захоронить его и назвать эту местность его именем. Впоследствии на месте захоронения был построен кумбез (могила), а сопка носит его имя до сегодняшнего дня [Жанайдаров, 2014, 5-6-бб.]

Курган Сарыадыр 2. Единственным культурным и датирующим элементом сооружения является стела с особенностью в ее установке - лежала плашмя в кольце ограды. Нам не удалось определить факт ее вертикальной позиции в конструкции. При вскрытии сооружения создалось впечатление, что стела была плашмя изначально помещена в контур кургана. Возможно, что при совершении ритуала она первоначально находилась в вертикальной позиции. После его завершения стела была уложена в ограду. 
В свое время А. Х. Маргуланом на основании визуальных данных о вертикально поставленных стелах в историческом ландшафте была «<... произведена первичная систематизации объектов и выделено четыре типа: округлые, не имеющие четких геометрических очертаний; высокие четырехгранные стелы, в сечении близкие к квадратной форме; высокие уплощенные стелы с зачатками стилизации морды животных; уплощенные стелы средних и малых размеров с полукруглым завершением» [Ярыгин, 2011, c. 410].

Значительная часть менгиров (стел) была включена в комплекс памятников бегазы-дандыбаевской культуры (БДК) эпохи поздней бронзы. Объекты, датированные этим периодом, названы как «койтасы» («бараньи камни»). Ученый предполагал, что в основе форм большинства стел представлен образ барана. Стелы занимают возвышенные места вблизи поселений, некрополей и рудников эпохи бронзы и являются своеобразными маркерами-символами определенных точек степного ландшафта. И только в единичных случаях имеют отношение к погребению [Маргулан, 1979, с. 276-277].

В дальнейшем типологизация А. Х. Маргулана была усовершенствована. В результате чего было выделено два основных типа, критерием для которых выступает расположение стелы на местности: одиночная установка; групповая [см. подробнее: Ярыгин, 2011, с. 408-416]. Стела сооружения Сарыадыр 2 относится к первому типу: установленный одиночный койmac с каменной постройкой. Только в этом случае койтас находится в горизонтальном положении.
Вертикальная постановка одиночной стелы в составе конструкции характерна для оленных камней Монголии, Тывы, Алтая (цит. Ковалев и др. по: [Ярыгин, 2011, с. 409]). При этом наиболее древними представляются изваяния без изображений. Культурный код стелы как ритуального объекта и образа символического маркера степного пространства восходит к эпохе палеометалла и получает продолжение в бегазы-дандыбаевское время. Архаическая традиция представлена в расположение стел в кольцевых оградках. Семантически и морфологически койтасы БДК входят в систему вертикально установленных стел, характерных для культурного ландшафта горностепного пространства Евразии от оленных камней Центральной Азии до киммерийских стел Восточной Европы и Северного Кавказа [Ярыгин, 2011, с. 410].

На основании вышесказанного курган Сарыадыр 2 со стелой можно отнести к категории ритуальных сооружений эпохи поздней бронзы. Отсутствие угольков, костей животных и т.п., характерных для жертвенных колец БДК, указывает на ритуальную особенность кургана, возможно, связанную с его сакральной миссией в ландшафте Караторгая. Стела со стилизованным образом бараньей головы является признаком бегазыдандыбаевской культовой традиции [Маргулан, 1979, с. 275-280]. Скорее всего, курган Сарыадыр 2 относится ко времени знаковой БДК Центрального Казахстана.

\section{Значение топонима Сарыадыр} и архаика сооружений. Топоним «Сарыадыр» по структуре является сложным и образован из двух слов: первое из них обозначает цвет «сары - желтое», а второе «адыр - сопка». Жел- 
тый цвет наряду с белым и черным наиболее часто встречается в казахской топонимике. Например, «Сарыарка», «Сарыбел», «Сарыагаш» и т.д. Первый компонент топонима «сары»» кроме цветового обозначения имеет значение «широкий, обширный, большой», что отмечено исследователями казахской топонимики. Вместе с тем, «слова ак и сар(ы) “белый” и “желтый” в космогоническом употреблении имели значение “запад” (-ный)» [Кононов, 1975, с. 176].

Слово «адыр» в казахском языке употребляется для обозначения возвышенности или сопок [Қазақ тілінің сөздігі, 1999, б. 16]. В этимологическом словаре казахского языка, исследуя происхождения слова «адырна», составителями отмечено, что оно производно от слова «адыр», которое в тюркских языках имело значение «разделить, развести» [Ысқақов, Сыздықов, Сарыбаев, 1966, б. 21]. Слово «адыр» редко встречается в казахскойгеографической номенклатуре в сочетании с цветовым обозначением (например, топоним «Ак-адыр»). Возможно, это связано со вторым или скрытым значением слова «адыр». В ходе этимологического исследования на этот факт обращает внимание исследователь Ә. Нұрмағанбетов: слово «адыр» имеет значение, близкое с «жынды (сумашедиий)». К такому выводу исследователь пришел, опираясь на толкование казахского слова «адыраю» (широко раскрытый глаз) и якутского слова «адырай», которое имеет значение «джин, шайтан (черт)» [Нұрмағанбетов, 1994, 6-7-бб.].

Смысловое значение топонима на первый взгляд может казаться простым и означать «желтая сопка».
Однако, учитывая ландшафтное положение топонима, вероятно, интерпретировать его как «западная отдельная сопка». Редкое употребление слова «aдыр» в тюркской топонимике предполагает и другое его значение как «запретная сопка». В этом контексте архаика исследованных сооружений с выраженным ритуальным характером в какой-то степени повлияла на происхождение данного топонима. Скрытый, культовый смысл сооружений был понятен, воспринят и сохранен кочевниками в названии одной из самых высоких сопок в ландшафте Караторгая.

Культовое значение памятников на сопке Cарыадыр. Традиционно средневековые святилищные комплексы кочевников располагались в ландшафте, природные позиции которого имели отличительные черты: урочища, участки расчлененного рельефа, возвышенное плато, уплощенные вершины крупных холмов. Определяется взаимосвязь возвышенных и сакральных объектов [Боталов, 2019, с. 299]. По всей видимости, традиция формирования поминальных культовых мест в ландшафте Караторгая относится к эпохе бронзы и получает дальнейшее развитие в XII-XIII вв. Исследованные сооружения подтверждают сакральную архетипичность значения сопки Сарыадыр в системе кочевнических культурных ценностей.

Благодарности. Благодарим за участие в археологических раскопках: А. К. Курмангалиева (Национальный музей РК), А. А. Молдахмета (КазНУ им. аль-Фараби), А. А. Сабыржана (заповедник-музей «Улытау»), В. Ю. Юсупова (г. Лисаковск). Приносим благодарность за помощь в организации работ экспедиции на 
местности Национальный историкокультурный и природный музейзаповедник «Улытау».

Высотную съемку осуществили: С. Ғ. Есен, докторант ЕНУ им. Л. Н. Гумилева; А. С. Омаров, докторант Карагандинского технического университета; И. А. Кузнецов, бакалавр технических наук, Караганды, Казахстан.

\section{ЛИТЕРАТУРА}

1. Бисембаев А.А. Археологические памятники кочевников средневековья Западного Казахстана (VIII-XVIII вв.). Уральск: изд-во Западно-Казахстанский областной центр истории и археологии, 2003. $232 \mathrm{c}$.

2. Боталов С.Г. У истоков южноуральских народов. Южный Урал в эпоху Золотой Орды (IX - начало XV века) // История Южного Урала: в 8 т. Челябинск: Издательский центр ЮУрГУ, 2019. Т. 5. 424 с.

3. Геологическая характеристика месторождения Кургасын. URL: https:// studbooks.net/1772478/geografiya/geologicheskaya_harakteristika\#16 (дата обращения: 11.11.2020).

4. Жанайдаров О.К. Қазақ жерінің 100 аңызы. Алматы: «Сораба» қоғамдық қоры. 2014. Т. 4.240 б.

5. Иванов В.И., Кригер В.А. Курганы кыпчакского времени на Южном Урале. М.: Наука, $1988.91 \mathrm{c}$.

6. Иванов В.И. «Кипчакизация» Урало-Поволжья по данным археологии // Тюркские кочевники Евразии (кимаки, кипчаки, половцы...): сб. ст. Сер. «Тюркские племена и государства Евразии в древности и в средние века». Казань: Изд-во «Ихлас»; Институт истории им. Ш. Марджани АН РТ, 2013. Вып. 2. С. 77-100.

7. Қазақ тілінің сөздігі. Алматы: Дайк-пресс, 1999. 776 б.

8. Каратургай, горный кряж. URL: https://ru.wikisource.org/wiki/ЭСБЕ/ Каратургай,_горный_кряж (дата обращения: 11.11.2020).

9. Кононов А.Н. Семантика цветообозначений в тюркских языках // Тюркологический сборник. М.: ГРВЛ; «Восточная литература», 1975 (1978). C. $159-179$.

10. Маргулан А.Х. Бегазы-дандыбаевская культура Центрального Казахстана. Алма-Ата: «Наука» КазССР, 1979. 360 с.

11. Могильников B.A. Памятники кочевников Сибири и Средней Азии XIII-XIV вв. // Степи Евразии в эпоху средневековья / Археология СССР. М.: Изд-во «Наука», 1981. C. 194-200.

12. Нұрмаванбетов Ә. Бес жүз бес сөз. Алматы: «Рауан», 1994. 304 б.

13. Усманова Э.Р., Дремов И.И., Панюшкина И.П., Колбина А.В. Монгольские воины Улуса Джучи по материалам могильника Карасуыр, Улытау // АЭАЕ. 2018. T. 46, № 2. C. 106-113.

14. ЫІсқақов А., Сыздықова Р., СарыбаевШ. Қазақ тілінің қысқашаэтимологиялық сөздігі. Алматы: Ғылым, 1966. 240 б.

15. Ярыгин С.A. «Койтасы» Центрального Казахстана эпохи поздней бронзы в контексте формирования раннесакской культуры Степной Евразии // Археология Казахстана в эпоху Независимости: итоги, перспективы: м-лы междунар. науч. конф., посвящ. 20-летию Независимости Республики Казахстан и 20-летию Института археологии им. А.Х. Маргулана КН МОН РК (г. Алматы, 12-15 декабря 2011 г.) / гл. ред. Б.А. Байтанаев, отв. ред. А.З. Бейсенов. Алматы: Институт археологии им. А.Х. Маргулана, 2011. Т. 1. С. 408-416. 


\section{REFERENCES}

1.Bisembayev,A.A. 2003. Arkheologicheskiyepamyatnikikochevnikovsrednevekoviya Zapadnogo Kazakhstana (VIII-XVIII vv.) (Archaeological sites of the nomads of the Middle Ages of Western Kazakhstan (VIII-XVIII centuries). Uralsk: West Kazakhstan regional center of history and archeology Publ. (in Russian).

2. Botalov, S. G. 2019. U istokov yuzhnouralskikh narodov. Yuzhnyy Ural v epokhu Zolotoy Ordy (IX-nachalo XV veka) (At the origins of the South Ural peoples. Southern Urals in the era of the Golden Horde (IX-early XV centuries). 8 vol. Vol. 5. Chelyabinsk: South Ural State University Publ. (in Russian).

3. Geologicheskaya harakteristika mestorozhdeniya Kurgasyn (Geological characteristics of the Kurgasyn deposit). URL: https://studbooks.net/1772478/geografiya/ geologicheskaya_harakteristika\#16

4. Janaydarov, O. K. 2014. Kazakh jerinin 100 anyz (100 Legends of the Kazakh land). Vol. 4. Almaty: "Soraba" Publ. (in Kazakh).

5. Ivanov, V. I., Kriger, V. A. 1988. Kurgany kypchakskogo vremeni na Yuzhnom Urale. (Mounds of the Kypchak time in the South Urals). Moscow: "Nauka" Publ. (in Russian).

6. Ivanov, V. I. 2013. In: Tyurkskiye kochevniki Yevrazii (kimaki, kipchaki, polovtsy...) (Turkic nomads of Eurasia (Kimaks, Kipchaks, Polovtsians...)). Vol. 2. Kazan: "Ikhlas" Publ.; Sh. Marjani Institute of History AN RT, 77-100 (in Russian).

7. Kazakh tilinin sozdigi (Dictionary of the Kazakh language). 1999. Almaty: "Dayk Press" Publ. (in Kazakh).

8. Kononov, A. N. 1975 (1978). Tyurkologicheskiy sbornik (Turkological collection). Moscow: "Eastern Literature" Publ., 159-179 (in Russian).

9. Karaturgaj, gornyj kryazh (Karaturgai, mountain range). URL: https:// ru.wikisource.org/wiki/ЭСБЕ/Каратургай,_горный_кряж

10. Margulan, A. Kh. 1979. Begazy-dandybayevskaya kultura Tsentralnogo Kazakhstana. (Begazy-Dandybay culture of Central Kazakhstan). Alma-Ata: "Nauka" KazSSR (in Russian).

11. Mogilnikov, V. A. 1981. In: Archeology of USSR. Moscow: "Nauka" Publ., 194-200 (in Russian).

12. Nurmaganbetov, A. 1994. Bes zhyz bes soz (Five hundred five words). Almaty: "Rauan" Publ. (in Kazakh).

13. Usmanova, E. R., Dremov, I. I., Panyushkina, I. P., Kolbina, A. V. 2018. In: Archeology, Ethnography and Anthropology of Eurasia, 46, No. 2, 106-113 (in Russian).

14. Yskakov, A., Syzdykova, R., Sarybayev, Sh. 1966. Kazakh tilinin kyskasha etymology sozdigi (Short Etymological Dictionary of the Kazakh language). Almaty: "Nauka" Publ. (in Kazakh).

15. Yarygin, S. A. 2011. In: Baitanayev, B. A., Beisenov, A. Z. (eds.). Arheologiya Kazahstana v epohu Nezavisimosti: itogi, perspektivy (Archeology of Kazakhstan in the era of Independence: results, prospects). Vol. 1. Almaty: A.Kh. Margulan Institute of Archeology, 408-416 (in Russian).

\footnotetext{
Мүдделер қақтығысы туралы ақпаратты ашу. Авторлар мүдделер қақтығысының жоқтығын мәлімдейді. / Раскрытие информации о конфликте интересов. Авторы заявляют об отсутствии конфликта интересов. / Disclosure of conflict of interest information. The authors claims no conflict of interest.

Мақала туралы ақпарат / Информация о статье / Information about the article. Редакцияға түсті / Поступила в редакцию / Entered the editorial office: 19.12.2020. Рецензенттер мақұлдаған / Одобрено рецензентами / Approved by reviewers: 05.01.2021. Жариялауға қабылданды / Принята к публикации / Accepted for publication: 19.01.2021.
} 